\title{
Comparative Analysis Regarding the Chemical and Microbiological Characteristics of Some Red Wine Assortments Produced in Two Romanian Viticultural Areas
}

\author{
THOMAS DIPPONG ${ }^{1 *}$, CRISTINA MIHALI ${ }^{1}$, ZORICA VOȘGAN $^{1}$, ALEXANDRA AVRAM $^{2}$, \\ ZOIȚA BERINDE ${ }^{\mathbf{1}}$, ANCA DUMUȚA ${ }^{\mathbf{1}}$ \\ ${ }^{1}$ Technical University Of Cluj Napoca, North University Center At Baia Mare, Faculty Of Science, 76 Victoriei Str., \\ 430122, Baia Mare, Romania0 \\ ${ }^{2}$ Babeş-Bolyai University, Faculty of Chemistry and Chemical Engineering, 11 Arany Janos, Str., 400028, Cluj-Napoca, \\ Romania
}

\begin{abstract}
Sweet, semi-dry and semi-sweet red wine samples from two vine-growing regions in Romania: Vrancea and Recass were analyzed aiming to show their main chemical properties including heavy metal content, and, microbiological characteristics. The chemical analysis showed that the semidry wine (WI) has a high polyphenol content, permanganate index and content of $\mathrm{Fe}, \mathrm{Zn}$ and $\mathrm{Cu}$, but the lowest content of anthocyanins, sugar and Mn; the total acidity of semi-sweet wine W3 was the highest, while the semi-sweet wine W2 contained the highest concentrations of anthocyanins and $\mathrm{SO}_{2}$. No contamination with yeasts, molds and bacteria was found when opening the wine bottles, these colonies having grown one month after opening. The importance of this article comes from the comprehensive presentation of the connections among the physicochemical and microbiological characteristics of sweet to semi-sweet red wines, or to semi-dry from two vinegrowing regions in Romania: Vrancea and Recaș.
\end{abstract}

Keywords: wine, chemical analysis, microbiological parameters

Wine is a complex matrix that contains water, sugar, alcohol, and a great variety of inorganic and organic components. The chemical composition of wine is influenced by many factors, including the grape variety, the geographical conditions, the soil's properties in the area of vine cultivation, the microbial ecology of the grape, the fermentation processes, and the winemaking technique [1,2]. The chemical composition of wine is influenced to a great extent by the microorganisms which metabolize grape carbohydrates during the stage of fermentation into ethanol, carbon dioxide and also a high number of secondary end-products [3]. The metal and trace metal content in wines is influenced by the soil characteristics of the vineyard and, also, by anthropogenic factors such as application of pesticides, fungicides and fertilizers containing $\mathrm{Cd}, \mathrm{Cu}, \mathrm{Mn}, \mathrm{Pb}$ and $\mathrm{Zn}$ compounds. Additionally, further contamination with metals can occur during the technological process of winemaking [1]. The contamination of wine with heavy metals such as $(\mathrm{Cd}, \mathrm{Pb}$ and $\mathrm{As})$ tends to happen, especially in the case of wines from vineyards located close to road traffic or in industrial areas, due to vehicle exhaust fumes or other emissions in the environment. Cadmium is a toxic element that enters the human body especially through food of vegetable and animal origin. $\mathrm{Cd}$ is more bioavailable to plants than $\mathrm{Pb}$. The content of metals in wines can be used to identify the geographic area of grape cultivation on the basis of the relationship with soil composition [1]. Other heavy metals such as $\mathrm{Cu}$ and $\mathrm{Fe}$ in wines are the factors to most likely lead to wine browning. Flavonoids present in wines interact with the metals through complexation, influencing the wine color that is mainly due to the flavonoid compounds.

The importance of this article comes from our comprehensive presentation of the detailed connections among the physicochemical and microbiological characteristics of sweet red wines to semi-sweet red wines, or to semi-dry from several vine-growing regions.

\section{Experimental part}

Five red wine varieties were purchased from the local market: 2 varieties of „Feteasca neagră” wines, semi-dry and semi-sweet, „Cabernet Sauvignon” semi-sweet, and, also, wines obtained by blending „Merlot” and „Pinot noir”. All the studied wines originating from different wine regions of Romanian vineyards, were codded as shown below.

W1 - "Feteasca neagră"- red semi-dry, wine area: Vrancea, Table wine.

W2 - Cabernet sauvignon - semi-sweet, wine area: Recas. High quality wine

*email: dippong.thomas@yahoo.ro 
W3 - "Feteasca neagră" - semi-sweet, wine area: Vrancea. High quality wine.

W4 - Merlot/Pinot noir - semisweet, Wine area: Recas. High quality wine.

W5 - Merlot/Cabernet - sweet, wine area: Vrancea. Table wine.

The total polyphenolic compounds (expressed as Folin Ciocalteu index) were measured according the OIV International Methods of Analysis of Wines and Musts (2015) by their oxidizing with Folin-Ciocalteu Reagent and the spectrophotometric measurement of the blue resulted compounds at $760 \mathrm{~nm}$ using a Lambda 25 Perkin-Elmer spectrophotometer. The measurement of anthocyanins by the sodium hydrogensulfite method is based on the property of the anthocyanins as well as that of the compounds containing flavin-groups to be discolored under the action of sulphur dioxde. The absorbances were measured using a Lambda 25 Perkin-Elmer spectrophotometer. Titrable acidity of wines was analyzed by titration against $\mathrm{NaOH} 0.1 \mathrm{~N}$ using the potentiometric method and was expressed as tartatric acid according to the OIV international method for the analysis of wines and musts (2015). The total sulfur dioxyde was measured according to the Romanian Standard 6182-18/2009 - the determination of reducing sugar in wine. The permangante index was measured by titration of the polyphenolic substances and other oxidable substances present in wine with potassium permanganate in the presence of $0.15 \mathrm{~g} / \mathrm{L}$ Indigo-Carmine as an oxydo-reduction indicator against a reference of tartaric-alcoholic solution. A $0.01 \mathrm{~N}$ potassium permanganate solution was freshly prepared from a $0.1 \mathrm{~N} \mathrm{KMnO}_{4}$ solution. The alcoholic solution of tartaric acid contains $10 \%$ volume of alcohol and $5 \mathrm{~g} / \mathrm{L}$ tartaric acid half neutralized with $1 \mathrm{~N} \mathrm{KOH}$. The sugar content was measured acoording to Romanian Standard 6182$18 / 2009$ regarding the determination of total and free $\mathrm{SO}_{2}$ in wine.

The heavy metals concentration in wine was measured by atomic spectrometry with a Perkin Elmer spectrophotometer. The analyzed heavy metals are both essential ( $\mathrm{Fe}, \mathrm{Mn}, \mathrm{Zn}, \mathrm{Cu}, \mathrm{Ni}$ and $\mathrm{Cr}$ ) and toxic metals $(\mathrm{Pb}$ and $\mathrm{Cd}$ ). The samples were mineralized with concentrated nitric acid. The Fe, $\mathrm{Mn}$ and $\mathrm{Zn}$ concentrations in wines were analyzed by flame absorption atomic spectrometry while the heavy metals at trace level such as $\mathrm{Ni}, \mathrm{Cr}, \mathrm{Pb}$ and $\mathrm{Cd}$ were analyzed by graphite furnace atomic absorption spectrometry technique with Zeeman background correction $[2,4,5]$.

The number of yeasts and molds present in wines at the opening of bottles and after one month of storage and consumption was determined according to a standardized method (STAS ISO 7954-2001 - General Directives for enumeration of yeasts and molds. Colony count technique at $25^{\circ} \mathrm{C}$ ) using Sabouraud Agar with Chloramphenicol as a culture medium.

\section{Results and discussion}

The biochemical, physicochemical and chemical processes which occurr during the transition from the enzymatic phase of the grape must to the aging of wines are very important in wine characterization. In addition to these features, the property to precipitate proteins, thus participating in the self-cleaning of wines, is also important, which is why red wines have a strong tonic effect on the body, playing the role of vitamin $\mathrm{P}$ and having a bactericidal power on pathogenic microorganisms [6]. The chemical composition of the wine samples was established and is presented in Table 1. The chemical composition of wine is very complex: besides ethanol, sugars and organic acids, wine contains polyphenols, aromatic, coloring substances such as anthocyanins and also minerals such as $\mathrm{Ca}, \mathrm{Mg}, \mathrm{Fe}, \mathrm{Mn}$ and microelements [7]. The polyphenols expressed as gallic acid varied within the range of 241-371 mg/L. The highest amount of polyphenols expressed as gallic acid was found in wine W1 and the lowest in wine W3 The acidity expressed as tartaric acid was balanced in all wines, varying slightly between 5.1 and $5.7 \mathrm{mg} / \mathrm{L}$. Polyphenols are substances with reductive properties with high importance in the redox reactions of wines, having antioxidant capacity.

The permanganate index values vary between 38.5 and 96 . One can notice that wines W2 and W3 are supple wines, while wines $\mathrm{W} 1, \mathrm{~W} 4$ and $\mathrm{W} 5$ are tough wines.

The highest anthocyanins content is observed in wine W5 and the lowest in wine W1. The anthocyanin content in red wine depends on several factors such as the grape variety, cultivation area, sun exposure, wine-making technique and wine age $[8,9]$. The anthocyanin content varies within the same wine cellar. Polyphenol, flavonoids, anthocyanins and tannins are substances with an noticeable complexing activity on metal ions, resulting in small changes in wine colour [10]. The highest content of sugar was found in wine W5, a sweet wine, while the lowest content was found in wine W1, a semi-dry wine. Ciubara et.al [11] reported slightly higher values $(646.045 \mathrm{mg} / \mathrm{L}$ for Feteasca Regala and $678.033 \mathrm{mg} / \mathrm{L}$ for Babeasca Neagra ) of anthocyanins in red wines produced in 2010, Iasi vineyard.

The heavy metal levels found were much below the maximum allowable limit according to the OIV (International Organisation of Vine and Wine). The variability of the metal content between the analyzed wine expressed as a coefficient of variation ranges between 3.6\% for $\mathrm{Mg}$ and $51.2 \%$ for Sn. Low variability was found for Ca (8.2), while other high coefficients of variation were found for $\mathrm{Cu}$ and $\mathrm{Cd}$ (Tabel 1). The $\mathrm{Cu}$ level in the analyzed wines ranges between 0.011 and $0.031 \mathrm{mg} / \mathrm{L}$, while the $\mathrm{Zn}$ level was between $0.27-0.52 \mathrm{mg} / \mathrm{L}$. 
Table 1

THE CHEMICAL PROPERTIES OF ANALYZED WINES

\begin{tabular}{|c|c|c|c|c|c|c|c|}
\hline $\begin{array}{c}\text { Sample } \\
\text { Parameter }\end{array}$ & Wine 1 & Wine 2 & Wine 3 & Wine 4 & Wine 5 & $\begin{array}{l}\text { OIV } \\
\text { Limit** }^{* *}\end{array}$ & $\begin{array}{c}\text { Coeff. of } \\
\text { variation \% }\end{array}$ \\
\hline $\mathrm{pH}$ & $3.58 \pm 0.04 c^{*}$ & $3.40 \pm 0.05 \mathrm{~b}$ & $3.53=0.04 c$ & $3.27 \pm 0.08 \mathrm{a}$ & $3.38 \pm 0.04 \mathrm{~b}$ & & 3.6 \\
\hline $\begin{array}{c}\text { Total acidity (as tartaric } \\
\text { acid } \mathrm{mg} / \mathrm{L} \text { ) }\end{array}$ & $5.33 \pm 0.58 \mathrm{a}$ & $5.10 \pm 0.35 \mathrm{a}$ & $5.70=0.31 \mathrm{a}$ & $5.18 \pm 0.53 a$ & $5.26 \pm 0.43 a$ & & 4.4 \\
\hline $\begin{array}{c}\text { Polyphenols } \\
\text { (gallic acid, } \mathrm{mg} / \mathrm{L}\end{array}$ & $371.0 \pm 11.4 \mathrm{~b}$ & $415 \cdot 3=9.5 \mathrm{c}$ & $241.0=7.6 \mathrm{a}$ & $246.7 \pm 8.3 a$ & $253.1=7.4 \mathrm{a}$ & & 26.75 \\
\hline $\begin{array}{c}\text { Anthocyanins(mg/L) } \\
\text { - at the bottles opening } \\
\text {-after a month from the } \\
\text { opening }\end{array}$ & $\begin{array}{l}113.8 \pm 5.7 \mathrm{a} \\
82.3 \pm 4 \mathrm{a}\end{array}$ & $\begin{array}{l}395.5 \pm 7.6 \mathrm{~d} \\
325.5 \pm 9.8 \mathrm{e}\end{array}$ & $\begin{array}{l}132.1 \pm 6.4 \mathrm{~b} \\
98.0 \pm 3.6 \mathrm{~b}\end{array}$ & $\begin{array}{c}245 \pm 6.6 c \\
159.3 \pm 4.5 c\end{array}$ & $\begin{array}{l}253.2 \pm 5.7 \mathrm{c} \\
172.4 \pm 4.1 \mathrm{~d}\end{array}$ & & $\begin{array}{l}49.8 \\
57.53\end{array}$ \\
\hline Content of Sugar(\%) & $1.06 \pm 0.07 \mathrm{a}$ & $4.27 \pm 0.22 \mathrm{~d}$ & $3.20 \pm 0.12 c$ & $2.84 \pm 0.15 b$ & $6.40 \pm 0.21 \mathrm{e}$ & & 54.1 \\
\hline Permanganate Index & $96.0 \pm 5.0 \mathrm{~d}$ & $44.5 \pm 3.5 b$ & $38.5 \pm 2.8 \mathrm{a}$ & $86.0=4.6 c$ & $89.2 \pm 4.6 \mathrm{~cd}$ & & 38.3 \\
\hline Total $\mathrm{SO}_{2}(\mathrm{mg} / \mathrm{L})$ & $41.0 \pm 3.0 \mathrm{~b}$ & $52.5 \pm 3.8 \mathrm{c}$ & $42.2 \pm 2.3 \mathrm{~b}$ & $32.0=2.2 a$ & $37.4 \pm 2.5 \mathrm{~b}$ & $40-55$ & 18.4 \\
\hline $\mathrm{As}(\mathrm{mg} / \mathrm{L})$ & $0.003=0.001 \mathrm{a}$ & $0.004 \pm 0.001 a b$ & $0.005 \pm 0.001 \mathrm{~b}$ & $0.002 \pm 0.001 \mathrm{a}$ & $0.003=0.001 a$ & 0.20 & 33.5 \\
\hline $\mathrm{Ca}(\mathrm{mg} / \mathrm{L})$ & $32.45 \pm 1.08 \mathrm{~b}$ & $35.55 \pm 1.18 \mathrm{c}$ & $37.24 \pm 1.73 \mathrm{c}$ & $33.24 \pm 1.24 \mathrm{~b}$ & $30.11=0.94 a$ & - & 8.2 \\
\hline $\mathrm{Cd}(\mathrm{mg} / \mathrm{L})$ & $\begin{array}{c}0.0027 \\
\pm 0.0001 \mathrm{bc}\end{array}$ & $\begin{aligned} & 0.0055 \\
\pm & 0.00017 \mathrm{~d}\end{aligned}$ & $\begin{array}{c}0.0028 \\
\pm 0.0001 \mathrm{c}\end{array}$ & $\begin{array}{c}0.0022 \\
\pm 0.0001 \mathrm{a}\end{array}$ & $\begin{aligned} & 0.0025 \\
\pm & 0.0001 \mathrm{~b}\end{aligned}$ & 0.01 & 42.6 \\
\hline $\mathrm{Cr}(\mathrm{mg} / \mathrm{L})$ & $0.065 \pm 0.003 b$ & $0.073=0.004 c$ & $0.051=0.002 \mathrm{a}$ & $0.085 \pm 0.004 \mathrm{~d}$ & $0.071=0.004 c$ & 0.10 & 18.0 \\
\hline $\mathrm{Cu}(\mathrm{mg} / \mathrm{L})$ & $0.031=0.001 \mathrm{e}$ & $0.019=0.001 \mathrm{c}$ & $0.014 \pm 0.001 \mathrm{~b}$ & $0.011=0.001 a$ & $0.028 \pm 0.001 d$ & 0.10 & 42.1 \\
\hline $\mathrm{Fe}(\mathrm{mg} / \mathrm{L})$ & $4.68 \pm 0.18 c$ & $4.18 \pm 0.19 \mathrm{~b}$ & $4.01 \pm 0.18 \mathrm{~b}$ & $2.79 \pm 0.13 a$ & $2.68 \pm 0.10 \mathrm{a}$ & 5.00 & 24.2 \\
\hline $\mathrm{Mg}(\mathrm{mg} / \mathrm{L})$ & $63.45 \pm 2.50 \mathrm{ab}$ & $65.32 \pm 2.32 \mathrm{~b}$ & $62.45 \pm 2.26 \mathrm{ab}$ & $60.57=2.21 \mathrm{a}$ & $66.25 \pm 2.62 \mathrm{~b}$ & - & 3.6 \\
\hline $\operatorname{Mn}(\mathrm{mg} / \mathrm{L})$ & $0.88 \pm 0.04 a$ & $2.39 \pm 0.08 \mathrm{~d}$ & $2.08 \pm 0.10 \mathrm{c}$ & $1.10 \pm 0.05 b$ & $1.21 \pm 0.05 b$ & - & 43.2 \\
\hline $\mathrm{Ni}(\mathrm{mg} / \mathrm{L})$ & $0.019 \pm 0.001 \mathrm{~b}$ & $0.015 \pm 0.001 \mathrm{a}$ & $0.025 \pm 0.001 \mathrm{c}$ & $0.042 \pm 0.002 \mathrm{e}$ & $0.039 \pm 0.002 \mathrm{~d}$ & 0.1 & 42.9 \\
\hline $\mathrm{Pb}(\mathrm{mg} / \mathrm{L})$ & $0.013 \pm 0.001 \mathrm{~b}$ & $0.019 \pm 0.001 d$ & $0.015 \pm 0.001 c$ & $0.010 \pm 0.001 \mathrm{a}$ & $0.011=0.001 a$ & 0.20 & 26.3 \\
\hline $\mathrm{Sn}(\mathrm{mg} / \mathrm{L})$ & $0.65 \pm 0.03 \mathrm{~b}$ & $1.32 \pm 0.04 \mathrm{~d}$ & $0.28 \pm 0.01 \mathrm{a}$ & $1.11=0.04 \mathrm{c}$ & $1.48 \pm 0.03 \mathrm{e}$ & 10.0 & 51.2 \\
\hline $\mathrm{Zn}(\mathrm{mg} / \mathrm{L})$ & $0.52 \pm 0.04 \mathrm{~d}$ & $0.27 \pm 0.02 a$ & $0.42 \pm 0.03 b$ & $0.47 \pm 0.03 c$ & $0.40 \pm 0.02 b$ & 5.00 & 22.6 \\
\hline
\end{tabular}

Values are presented as means \pm standard deviation

${ }^{*}$ Different letters within a line indicate significant differences for Fisher's LSD test and $\mathrm{p}<0.05$

**OIV -International Organization of Vine and Wine

Investigation of mineral elements such as $\mathrm{Fe}, \mathrm{Mn}, \mathrm{As}, \mathrm{Zn}, \mathrm{Pb}, \mathrm{Cd}, \mathrm{Ni}, \mathrm{Cu}, \mathrm{Cr}$ is important to establish possible contamination of wine, and, also, because they could serve as indicators of wine authenticity [7]. Similar values were reported in other wine regions in Romania [5] and Serbia [4]. It was demonstrated that $\mathrm{Cu}$ and $\mathrm{Zn}$ chelate with the polyphenols contained in wine as catechin, rutin and quercetin. During winemaking, the polyphenols or anthocyanins concentrations increased while $\mathrm{Cu}$ and $\mathrm{Fe}$ contents decreased, and, at the same time, a browning of quercetin and rutin took place due to the flavonol oxidation through reactive oxygen species formation [10].

$\mathrm{Cu}$ reacts with the thiol groups of proteins, forming precipitates that settle at the bottom of the bottle and negatively influence the limpidity of wine [12]. Cu in wine can come from several sources: from the soil due to copper accumulation in the vineyard's soil, caused by the $\mathrm{CuSO}_{4}$ treatment applied as a fungicide, from the winery equipment, and, also, from the use of $\mathrm{Cu}$ in fining purposes $[10,12]$. The main source of $\mathrm{Cu}$ in the finished wine is the addition of $\mathrm{CuSO}_{4}$ for the elimination of hydrogen sulfide [10]. A high residual content of $\mathrm{Cu}$ in wines is undesirable because it can contribute to an increased rate of oxidative processes that finally results in wine browning and the deterioration of some sensory attributes such as the loss of aromatic freshness and, in the final stage, the formation of precipitates consisting of condensed phenolic products at the bottom of the bottled wines $[7,10,13]$. The $\mathrm{Zn}$ sources in wines are related to technological processes and the use of some phytosanitary substances [13]. The other trace elements such as $\mathrm{As}, \mathrm{Cd}$ and $\mathrm{Pb}$ low concentration reflect differences between the grape variety, environmental factors, as well as winemaking technology that has an anthropogenic impact [4]. The highest content of As was found in wine $\mathrm{W} 3$, while the highest level of $\mathrm{Cd}$ and $\mathrm{Pb}$ was determined in wine $\mathrm{W} 2$. The low As level indicates that arsenate pesticides were not used during the growth of the grapes.

Some of these trace elements such as $\mathrm{Cu}, \mathrm{Fe}$, and $\mathrm{Mn}$ have an organoleptic effect, and also a special contribution to the haze and taste of wines [14]. Fe concentrations in the analyzed wines ranged between 2.68 and $4.68 \mathrm{mg} / \mathrm{L}$, with a coefficient of variation of $24.2 \%$, while the Mn level was lower, between 0.88 and $2.39 \mathrm{mg} / \mathrm{L}$, showing a higher variability, of $43.2 \%$. The Fe content in wine is important due to its effect on the undesirable process of oxidation [15]. Literature studies concluded that a small quantity of iron in wines produces an increment of blue colour and a decrease of red colour [10]. Fe can cause quality problems in wines, particularly when the equipment in the winemaking process is made of Fe [13]. The limit for the Mn concentration in wine was not established, but it is important to know the concentration due to the influence of $\mathrm{Mn}$ on wine oxidation [15]. In the analyzed wines, $\mathrm{Mn}$ levels ranged between $0.88-2.39 \mathrm{mg} / \mathrm{L}$. The recommended level for $\mathrm{Mn}$ in wine is of less than $2 \mathrm{mg} / \mathrm{L}$ but for European wines an average value of $2.7 \pm 1.7$ was reported [16]. Cr concentrations in wines varied between 0.051 and $0.085 \mathrm{mg} / \mathrm{L}$ with an average value of $0.069 \mathrm{mg} / \mathrm{L}$. Usually, an increase of $\mathrm{Cr}$ content during wine storage occurs as a 
result of contamination during storage in stainless steel containers or in bottles colored with pigments based on chromium oxides [10].

$\mathrm{Pb}$ concentrations of analyzed wines were in the range of $0.01-0.019 \mathrm{mg} / \mathrm{L}$ with a relative low variability, of $26.3 \%$, while $\mathrm{Sn}$ level were $0.28-1.48$, showing a high variability $(51.2 \%)$. $\mathrm{Pb}$ sources in wines are the pollution of the grapes with leaded gasoline, tin-capsules used to cover the neck of the wine bottle and brass alloys used in wine making processes [10]. In the studied wines, Ni ranged between 0.015 and $0.042 \mathrm{mg} / \mathrm{L}$. $\mathrm{Ni}$ in wine can come from the dissolving process of $\mathrm{Ni}$ from nickel alloys in stainless steel and, also, due to the contact with asbestos or nickelcontaining enamels [17]. High levels of Ca can cause calcium tartrate precipitation [10].

Cluster analysis of heavy metal and As content in W1-W5 wine assortments was performed with Statgraphics programme. The dendrogram in Figure 1 shows the similarities between these elements and their possible origine in wine composition, such as, soil, the treatment of vines, contact with stainless steel or the stages of wine making processes.

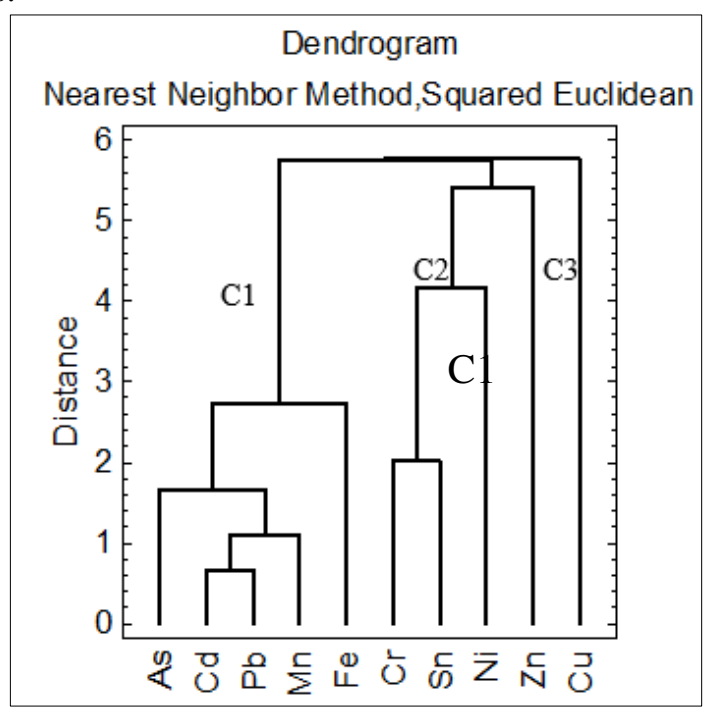

Fig. 1. Cluster analysis of the heavy metal and As content, variables in the classification of wines W1-W5

The main clusters $\mathrm{C} 1-\mathrm{C} 3$ were generated: $\mathrm{C} 1$ is composed of $\mathrm{As}, \mathrm{Cd}-\mathrm{Pb}$ pair that showed the highest similarity linked to $\mathrm{Mn}$ and, at higher distance to $\mathrm{Fe}$. These elements in wines originated especially from soil and from the contact with techological lines or containers during the processing. $\mathrm{C} 2$ contained the metals found as component of stainless steel such as $\mathrm{Cr}, \mathrm{Ni}$ and $\mathrm{Zn}$. The presence of these elements in wine could be ascribed to their absorption from soil and sources such as fertilizer, agricultural chemicals and contaminants, to agricultural mechanization procedures, sprays, seed preservatives and also to the winemaking process [4]. $\mathrm{Cu}$ formed a distinguished cluster, $\mathrm{C} 3$. $\mathrm{Cu}$ is used as an antifungal agent in the treatment of vines and, also, for wine fining purposes.

While microorganisms such as lactic acid bacteria are a crucial part of the natural microbiota of wine, positively influencing its characteristics, others can also cause spoilage problems, thus decreasing the quality of wine [18]. No contamination with yeasts, molds and bacteria was found when opening the wine bottles, which proves that wines presented a high microbiological quality. The appearance of molds was observed by repeating the analyses at one month after the opening of bottles; their development was caused by external contaminants (from the air, when opening the containers) as the analysis results can illustrate, in Figure 2a for semi-dry wines (W1) and sweet wines (W2, W3, W4). This can also be explained by the fact that while microorganisms can originate from the grape and specific vineyard, they need oxygen to develop, normaly lacking because of the oxygen-free athmosphere in winemaking due to the high $\mathrm{CO}_{2}$ content produced at the turning of sugars into alcohool through yeast. Molds generate metabolites of a strong sensory perception that can highly influence the wine quality $[19,20]$.

(a)
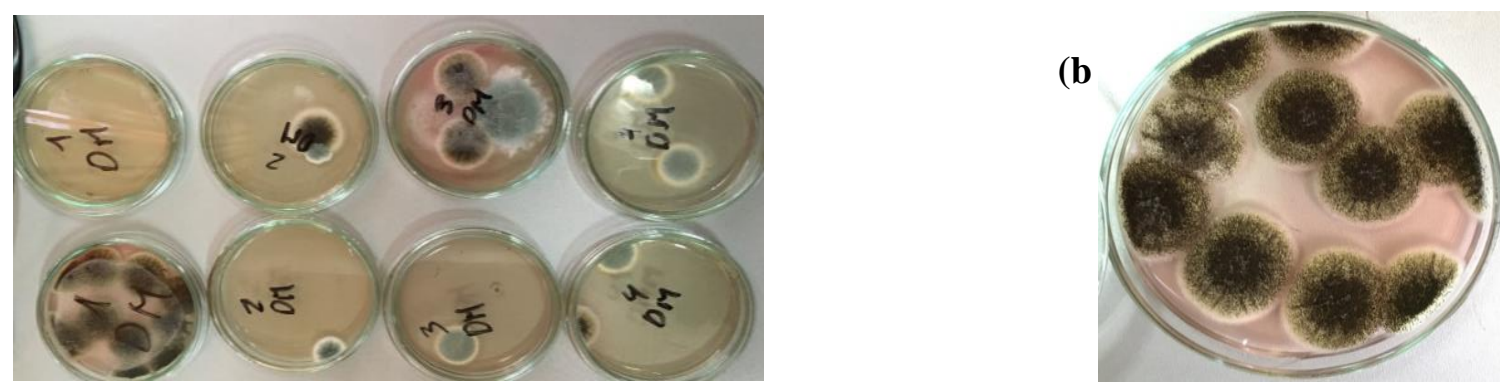

Fig. 2. Yeasts and molds contamination of the wine samples W1, W2, W3, W4 at one month after bottles opening (a) and the wine samples W4 at one month after opening (b) 
In Figure 2, a noticeable development of the microorganisms in the sweet wine (W5) can be observed. The number of colonies of yeasts and molds found in the wine one month later after opening the wine bottles were: 1.5 (W1), 2.5 (W2) 2.0 (W3), 5.5 (W4) and 9.4 (W5) number of colonies / $\mathrm{mL}$ of wine. The development of bacteria, and the increase in wine life can be controlled through increasing of the acidity, a parameter controlled by regulations [18]. However, molds can grow within a wide range of $\mathrm{pH}$ (1.5 to 9), with an optimal value in the acid medium, which indicates that the acidic $\mathrm{pH}$ of the analyzed samples situated between 3.27- 3.58 is a favorable environment for the growth of molds. Also, a decrease of the anthocyanin content can be noticed at one month after opening, a phenomenon also influenced by the development of molds, because the molds contamination accelerate color degradation [21]. Taking the self-association into account, the copigmentation influences the anthocyanin concentration the most, followed by the equilibrium and color response [22].

As reported in literature [13], anthocyanins have a stimulating effect on the growing of lactic acid bacteria, has the capacity to turn wine into vinegar. An increase in the bacterial population can be explained through the using of glucose in anthocyanins as an energy source. As molecules that can be seen as a hydrogen acceptor or fermentation substrate can lead to further lactic acid bacterial growth [13], phenolic compounds can contribute to this process through the release of small quantitaties of fermentable sugar.

\section{Conclusions}

The analysis of heavy metal content showed values under the limits fixed by the OIV and a relatively large variation between the analyzed samples for $\mathrm{Sn}, \mathrm{Cu}$ and $\mathrm{Cd}$. Additionally, some chemical parameters were investigated showing differences in composition among the wine samples. The acidic $\mathrm{pH}$ favors the development of molds in wine; the sweet wine W5 was the most contaminated, in which, a significant anthocyanin content reduction one month after the opening of the container was also observed. The semi-dry wine (W1) has the highest polyphenols content, the highest permanganate index and also the highest content of $\mathrm{Fe}, \mathrm{Zn}$ and $\mathrm{Cu}$ but the lowest content of anthocyanins, sugar and Mn. The total acidity of semi-sweet wine W3 was the highest, while the semi-sweet wine W2 contained the highest concentrations of anthocyanins and $\mathrm{SO}_{2}$. This study is very useful because it presents a comprehensive overview of red, sweet, semi-sweet, semi-dry wines in sensory, physicochemical and microbiological terms, with emphasis on metal content. Through this approach, differences in wines from different geographic regions have also been identified.

\section{References}

1. WOLDEMARIAM, D.M., CHANDRAVANSHI, B.S., B. Chem. Soc. Ethiopia, 25, 2011, p. 169.

2. VOICA, C., DEHELEAN, A., PAMUlA, A., J. Phys. Conf. Ser., 182, 2009, p. 1.

3. FLEET, G.H., Int. J. Food. Microbiol., 86, 2003, p. 11.

4. KOSTIĆ, D., MITIĆ, S., MILETIĆ, G., DESPOTOVIĆ, S., ZARUBICA, A., J. Serb. Chem. Soc., 75, 2010, p. 1701.

5. BORA, F.D., BUNEA, C.I., RUSU, T., POP, N., Chem. Cent. J., 9, 2015, p. 19

6. LI, H., GUO, A., WANG, H., Food Chem., 108, 2008, p. 1.

7. RUSTIONI, I., J, Enol, Vitic., 36, 2015, p. 387.

8. OPRICA, L., ANTOHE, R.G., VERDEȘ, A., GRIGORE, M.N., Rev. Chim. (Bucharest), 70, no. 2, 2019 , p.491.

9. ARAUJO, P.F., NITZKE, J.A., KLIPEL, C.B., VOGT DE JONG, E., Food Chem., 120, 2010 , p. 109.

10. PYRZYNSKA, K., Chem. Spec. Bioavailab., 19, 2007, p. 1.

11. CiUBARA, A.B., TUdOR, R.C., NECHITA, L., TITA, O., ANAMARIA CIUBARA, A., TURLIUC, S., RAFTU, G., Rev. Chim. (Bucharest), 69, no. 5, 2018, p.1247.

12. HOPFER, H., NELSON, J., MITCHELL, A.E., HEYMANNA, H., EBELERAD, S.E., J. Anal. At. Spectrom., 28, 2013, p. 1288.

13. VILELA, A., MONTEIRO, B., CORREIA, E., Cienc. Tec. Vitivinic., 30, 2015, p. 1.

14. KOKKINOFTA, R., ECONOMIDOU, N., TZIONI, E., DAMIANOU, K., POULLI, K., SAVVIDOU, C., LOUKA, C., KANARI, P, J. Chem. Chem. Eng., 8, 2014, p. 101.

15. CACHO, J., CASTELLS, J.E., ESTEBAN, A., LAGUNA, B., SAGRISTA, N., Am. J. Enol. Viticult., 43, 1995 , p. 380.

16. STOBBAERTS, R., ROBBERECHT, H., HAESEN, F., DEELSTRA, H., Int. J. Vitam. Nutr. Res., 64, 1994, p. 233.

17. OUGH, C.S., AMERINE, M.A., Methods for analysis of Musts and Wines. University of California, 2, John Wiley \& Sons, New York.

18. BARTOWSKY, E.J., Lett. Appl. Microbiol., 48, 2009, p. 149.

19. DONNELLY, D.M., Am. J. Enol. Viticult., 28, 1977, p. 176.

20. FUGELSANg, K.C., EDWARDS, C.G., Wine Microbiology, Practical Apllications and Procedures, 2 , Springer, 2013.

21. PILANDO, L., WROLSTAD, R., HEATHERBELL, D.A., J. Food Sci., 50, 1985, p. 1121.

22. BOULTON, R., Am. J. Enol. Viticult., 52, nr. 2, 2001, p. 67.

Manuscript received: 20.03 .2019 